\title{
Differential Regulation of the Mesoaccumbens Dopamine Circuit by Serotonin2C Receptors in the Ventral Tegmental Area and the Nucleus Accumbens: An In Vivo Microdialysis Study with Cocaine
}

\author{
Sylvia Navailles', Delphine Moison', Kathryn A Cunningham² and Umberto Spampinato*,' \\ 'Unité Mixte de Recherche-Centre National de la Recherche Scientifique (UMR-CNRS) 554I, Université Victor Segalen Bordeaux 2, Bordeaux \\ Cedex, France; ${ }^{2}$ Center for Addiction Research and Department of Pharmacology and Toxicology, University of Texas Medical Branch, \\ Galveston, TX, USA
}

\begin{abstract}
Stimulation of central serotonin2C receptor $\left(5-\mathrm{HT}_{2} \mathrm{C}\right.$ ) inhibits dopamine (DA)-dependent neurochemical and behavioral effects of cocaine, while 5- $\mathrm{HT}_{2} \mathrm{C}$ Rs locally expressed into the ventral tegmental area (VTA) and the nucleus accumbens (NAc) exert opposite functional control over cocaine-induced behavioral effects. Using in vivo microdialysis in halothane-anesthetized rats, we tested the hypothesis that this functionally opposite regulation of the mesoaccumbens DA pathway relies on the ability of 5-HT $2 \mathrm{C} R$ in the VTA and the NAc to inhibit and enhance respectively cocaine-induced accumbal DA outflow. Intra-VTA injection of the 5-HT2CR agonist Ro 600175 at $5 \mu \mathrm{g} / 0.2 \mu \mathrm{l}$, but not I $\mu \mathrm{g} / 0.2 \mu \mathrm{l}$, attenuated the increase in accumbal DA outflow induced by the systemic administration of I $0 \mathrm{mg} /$ $\mathrm{kg}$ of cocaine. Intra-VTA injection of the $5-\mathrm{HT}_{2} \mathrm{C}$ antagonist SB 242084 at either dose $(0.1$ or $0.5 \mu \mathrm{g} / 0.2 \mu \mathrm{l})$ did not modify the effects of cocaine. Intra-NAc application of Ro 60-0 175 dose-dependently excited $(0.1 \mu \mathrm{M})$ and inhibited $(\mathrm{I} \mu \mathrm{M})$ cocaine-induced DA outflow. In contrast, intra-NAc application of SB 242084 resulted in diametrically opposite effects when applied at these concentrations. These results further support the idea that the overall action of central $5-\mathrm{HT}_{2} \mathrm{CRs}$ on accumbal DA output is dependent, at least in part, on the functional balance between different $5-\mathrm{HT}_{2} \mathrm{C}$ populations within the NAc and within the mesoaccumbens DA pathway (VTA vs NAc). Neuropsychopharmacology (2008) 33, 237-246; doi:I0.I038/sj.npp. I30 I4|4; published online II April 2007
\end{abstract}

Keywords: 5- $\mathrm{HT}_{2 \mathrm{C}}$ receptor; cocaine; ventral tegmental area; nucleus accumbens; accumbal dopamine release; rat

\section{INTRODUCTION}

The mesolimbic dopamine (DA)ergic pathway originating from the ventral tegmental area (VTA) and projecting to the nucleus accumbens (NAc) (Azmitia and Segal, 1978) plays an important role in mediating the behavioral effects of drug of abuse, such as cocaine (Cunningham and Callahan, 1991; Kalivas and Nemeroff, 1988; Koob, 1992). During recent years, numerous studies have focused on the role of the serotonergic2 $\mathrm{C}$ receptor $\left(5-\mathrm{HT}_{2 \mathrm{C}} \mathrm{R}\right)$ in the modulation of this DA pathway and its potential to control cocaine dependence (Bubar and Cunningham, 2006; Di Matteo et al, 2002; Higgins and Fletcher, 2003). Indeed, $5-\mathrm{HT}_{2 \mathrm{C}} \mathrm{Rs}$ are densely localized in brain regions containing DA cell bodies (VTA) and terminals (NAc) (Bubar and Cunningham, 2006;

*Correspondence: Dr U Spampinato, Université Victor Segalen Bordeaux 2, Center Recherche Inserm U862, Institut Francois Magendie, 146 rue Léo Saignât, B.P. 59, Bordeaux Cedex, 33076, France, Tel: + 335575737 57, Fax: + 335575736 69,

E-mail: umberto.spampinato@bordeaux.inserm.fr

Received 13 October 2006; revised I4 February 2007; accepted 6 March 2007
Clemett et al, 2000; Pazos et al, 1985; Pompeiano et al, 1994), and are known to modulate DA-dependent behavior$\mathrm{al}$ and neurochemical effects induced by cocaine (Fletcher et al, 2002, 2006; Grottick et al, 2000; McCreary and Cunningham, 1999; Navailles et al, 2004). Specifically, the systemic administration of the $5-\mathrm{HT}_{2 \mathrm{C}} \mathrm{R}$ agonist Ro 60-0175, and the $5-\mathrm{HT}_{2 \mathrm{C}} \mathrm{R}$ antagonist SB 242084 has been shown to respectively inhibit and potentiate cocaineinduced behaviors including its hypermotive and rewarding effects (Fletcher et al, 2002, 2006; Grottick et al, 2000). Conversely, cocaine-induced DA release in the NAc is potentiated by the intraperitoneal administration of SB 242084 , but unaltered by the intraperitoneal administration of Ro 60-0175 (Navailles et al, 2004).

Recent intracranial microinjection studies aimed to identify the site(s) of action for the modulatory control of $5-\mathrm{HT}_{2 \mathrm{C}} \mathrm{R}$ within the mesoaccumbens pathway have shown that cocaine-induced DA behavior undergoes distinctly regional regulation by $5-\mathrm{HT}_{2 \mathrm{C}} \mathrm{Rs}$ located in the VTA and in the medio-ventral subdivision (shell) of the NAc (Filip and Cunningham, 2002; Fletcher et al, 2004; McMahon et al, 2001). Intra-VTA injection of the $5-\mathrm{HT}_{2 \mathrm{C}} \mathrm{R}$ agonist Ro 
60-0175 (Fletcher et al, 2004), but not of the $5-\mathrm{HT}_{2 \mathrm{C}} \mathrm{R}$ antagonist RS 102221 (McMahon et al, 2001), reduced cocaine-induced hyperlocomotion and self-administration. In line with the idea that the VTA may represent a primary site of action for the inhibitory control of the mesoaccumbens DA pathway by $5-\mathrm{HT}_{2 \mathrm{C}} \mathrm{Rs}$ (Di Matteo et al, 2002; Grottick et al, 2000; Navailles et al, 2004), it was concluded that VTA $5-\mathrm{HT}_{2 \mathrm{C}} \mathrm{R}$ stimulation was sufficient to attenuate the locomotor and reinforcing effects of cocaine (Fletcher et al, 2004). On the other hand, intra-NAc shell injections of $5-\mathrm{HT}_{2 \mathrm{C}} \mathrm{R}$ agonists and antagonists have been shown to respectively increase and decrease the hyperlocomotive and discriminative stimulus effects of cocaine (Filip and Cunningham, 2002; McMahon et al, 2001). Thus, in contrast to the overall inhibitory influence of systematically administered $5-\mathrm{HT}_{2} \mathrm{R}$ compounds on DA-dependent behaviors (Callahan and Cunningham, 1995; Filip et al, 2004; Fletcher et al, 2002; 2006; Frankel and Cunningham, 2004; Grottick et al, 2000), these results suggest that $\mathrm{NAc} 5-\mathrm{HT}_{2 \mathrm{C}} \mathrm{Rs}$ exert an excitatory control on accumbal DA function (Bowers et al, 2000; Dremencov et al, 2005; Yan, 2000). Furthermore, considering that cocaine-induced behavior is thought to result from increased DA efflux in the NAc (Di Chiara, 2002; Dunnett and Robbins, 1992), these data suggest the existence of a functional opposite control of cocaineinduced accumbal DA outflow by $5-\mathrm{HT}_{2 \mathrm{C}} \mathrm{Rs}$ in the VTA (inhibition) and NAc (excitation) (Filip and Cunningham, 2002). However, direct neurochemical evidence for this hypothesis is still lacking.

The present study was therefore designed to determine the relative contribution of VTA and NAc $5-\mathrm{HT}_{2 \mathrm{C}} \mathrm{Rs}$ in the control of cocaine-induced accumbal DA outflow, to specifically identify the nature (inhibition/excitation) of this control in each brain region. Experiments were performed using in vivo microdialysis in halothane-anesthetized rats, an experimental procedure allowing simultaneous implantation of a dialysis cannula in the NAc and an injection cannula in the ipsilateral VTA (Ikemoto et al, 1997; McMahon et al, 2001). A selective $5-\mathrm{HT}_{2 \mathrm{C}} \mathrm{R}$ agonist (Ro 60-0175) and antagonist (SB 242084) were applied locally into the VTA or the NAc before the intraperitoneal administration of cocaine.

\section{MATERIALS AND METHODS}

\section{Animals}

Male Sprague-Dawley rats (IFFA CREDO, Lyon, France) weighing $330-380 \mathrm{~g}$ were used. Animals were kept at constant room temperature $\left(21 \pm 2^{\circ} \mathrm{C}\right)$ and relative humidity $(60 \%)$ with a 12-light/dark cycle (dark from $20: 00 \mathrm{~h}$ ) and had free access to water and food. All animal use procedures conformed to International European Ethical Standards (86/ 609-EEC) and the French National Committee (décret 87/ 848 ) for the care and use of laboratory animals. All efforts were made to minimize animal suffering and to reduce the number of animals used.

\section{Drugs}

The following compounds were used: Ro $60-0175 . \mathrm{HCl}$ (S-2-(6-chloro-5-fluoroindol-1-yl)-1-methylethylamine.hydro- chloride) kindly donated by Dr P. Weber (F Hoffmann-La Roche, Basel, Switzerland); SB $242084.2 \mathrm{HCl}$ (6-chloro5-methyl-1-(6-(2-methylpiridin-3-yloxy)pyridin-3-yl carbamoyl) indoline dihydrochloride) was purchased from Sigma-RBI (Saint Quentin Fallavier, France). Cocaine hydrochloride was purchased from Calaire Chimie (Calais, France). All others chemicals and reagents were the purest commercially available (VWR, Strasbourg, France; Sigma, Illkirch, France).

\section{Microdialysis}

Surgery and perfusion procedures were performed as described previously (De Deurwaerdère et al, 2004), with minor modifications. Briefly, rats were anesthetized with a mixture of halothane and nitrous oxide-oxygen (2\%; $2: 1, \mathrm{v} / \mathrm{v})$. After tracheotomy for artificial ventilation, the animals were placed in a stereotaxic frame, and their rectal temperature was monitored and maintained at $37.3^{\circ} \mathrm{C} \pm 0.1$ with a heating pad. A microdialysis probe $(2 \mathrm{~mm}$ long, CMA/11, $240 \mu \mathrm{m}$ outer diameter, Cuprophan; Carnegie Medicin, Phymep, Paris, France) was implanted in the medio-ventral part of the right NAc, corresponding to the shell subdivision (coordinates from interaural point: anteroposterior $(\mathrm{AP})=10.7$, lateral $(L)=1$, ventral $(V)=2)$ according to the atlas of Paxinos and Watson (1986). The probe was perfused at a constant flow rate of $2 \mu \mathrm{l} / \mathrm{min}$ by means of a microperfusion pump (CMA 111, Carnegie Medicin, Phymep) with artificial cerebrospinal fluid (aCSF) containing (in $\mathrm{mM}$ ): $154.1 \mathrm{Cl}^{-}, 147 \mathrm{Na}^{+}, 2.7 \mathrm{~K}^{+}, 1 \mathrm{Mg}^{2+}$, and $1.2 \mathrm{Ca}^{2+}$, adjusted to $\mathrm{pH} 7.4$ with $2 \mathrm{mM}$ sodium phosphate buffer. Dialysates $(30 \mu \mathrm{l})$ were collected on ice every $15 \mathrm{~min}$. The in vitro recovery of the probe was about $10 \%$ for DA.

Drug applications into the NAc were performed via the dialysis probe after the stabilization of DA levels in the perfusate (see 'Pharmacological treatments' section) by reverse dialysis. Drug or corresponding vehicle was administered at a flow rate of $2 \mu \mathrm{l} / \mathrm{min}$ by means of a three-way liquid switch system (CMA 111, Carnegie Medicin, Phymep) taking into account the total dead volume of the perfusion system.

\section{Surgical Implantation of Cannulae and Microinjection Protocol}

Drug applications into the VTA were performed after the stabilization of DA levels in the perfusate (see 'Pharmacological treatments' section). A stainless-steel cannula $(30 \mathrm{G})$ was stereotaxically lowered into the VTA through a previously drilled hole. Stereotaxic coordinates were chosen taking into account the topographical organization of DA projections (Ikemoto et al, 1997) to target the anterior subdivision of the VTA (coordinates from interaural point: $\mathrm{AP}=4, L=0.8$, and $V=2$ (Paxinos and Watson, 1986)) mainly connected to the shell compartment of the NAc. Drug or corresponding vehicle was delivered into the VTA in a final volume of $0.2 \mu \mathrm{l}$ at a constant flow rate of $0.1 \mu \mathrm{l} /$ min by a $10 \mu \mathrm{l}$ Exmire syringe and a syringe pump (CMA 400, Carnegie Medicin, Phymep). After completion of the microinjection, the injection cannula was left in place for an 
additional 5 min before withdrawal to allow diffusion from the tip and prevent reflux of the solution injected.

\section{Histology}

At the end of each experiment, the brain was removed and fixed in $\mathrm{NaCl}(0.9 \%) /$ paraformaldehyde solution (10\%). The location of the microdialysis probe into the NAc and the stainless-steel cannula into the VTA were determined histologically on serial coronal sections $(60 \mu \mathrm{m})$ stained with cresyl violet, and only data obtained from rats with correctly implanted probes were included in the results. No significant tissue damage was evident upon histological examination of sections.

\section{Chromatographic Analysis}

Dialysate samples were immediately analyzed by reversephase high-performance liquid chromatography coupled with electrochemical detection, as described previously (Porras et al, 2002). The mobile phase (containing (in mM) $70 \mathrm{NaH}_{2} \mathrm{PO}_{4}, 0.1 \mathrm{Na}_{2}$ EDTA, 0.7 triethylamine, and 0.1 octylsulfonic acid plus $10 \%$ methanol, adjusted to $\mathrm{pH} 4.8$ with orthophosphoric acid) was delivered at $1 \mathrm{ml} / \mathrm{min}$ flow rate (system LC-10AD-VP, Shimadzu, Champs s/Marne, France) through a Hypersyl column $\left(\mathrm{C}_{18} ; 4.6 \times 150 \mathrm{~mm}\right.$, particle size $5 \mu \mathrm{m}$; Touzard \& Matignon, Paris, France). Detection of DA was carried out with a coulometric detector (Coulochem II, ESA, Paris, France) coupled to a dualelectrode analytical cell (model 5014, ESA). The potential of the electrodes was set at -175 and $+175 \mathrm{mV}$. Output signals were recorded on a computer (system class VP-4, Shimadzu, France). Under these conditions, the sensitivity for DA was $0.5 \mathrm{pg} / 30 \mu \mathrm{l}$ with a signal/noise ratio of $3: 1$.

\section{Pharmacological Treatments}

Pharmacological treatments were performed after the stabilization of DA levels in the perfusate. A stable baseline, defined as three consecutive samples, in which DA contents varied by less than $10 \%$, was generally obtained $135 \mathrm{~min}$ after the beginning of the perfusion (stabilization period).

Cocaine was diluted in $0.9 \% \mathrm{NaCl}$, and administered intraperitoneally at $10 \mathrm{mg} / \mathrm{kg}$ in a volume of $2 \mathrm{ml} / \mathrm{kg}$ (Filip and Cunningham, 2002; Fletcher et al, 2004; McMahon et al, 2001). The $5-\mathrm{HT}_{2 \mathrm{C}} \mathrm{R}$ agonist Ro $60-0175$ was dissolved in $0.9 \% \mathrm{NaCl}$, and administered either into the VTA ( 1 and $5 \mu \mathrm{g} / 0.2 \mu \mathrm{l}$, microinjections) or into the NAc $(0.1$ and $1 \mu \mathrm{M}$, reverse dialysis) $15 \mathrm{~min}$ before the systemic administration of cocaine. The selective 5- $\mathrm{HT}_{2 \mathrm{C}} \mathrm{R}$ antagonist SB 242084 was dissolved in $0.9 \% \mathrm{NaCl}$, and administered either into the VTA ( 0.1 and $0.5 \mu \mathrm{g} / 0.2 \mu \mathrm{l}$, microinjections) or into the NAc (0.1 and $1 \mu \mathrm{M}$, reverse dialysis) $15 \mathrm{~min}$ before the systemic administration of cocaine.

For microinjection in the VTA, the final solution of each 5- $\mathrm{HT}_{2 \mathrm{C}} \mathrm{R}$ compound was adjusted to $\mathrm{pH}$ 6-7 before injection. The corresponding vehicle solution at $\mathrm{pH}$ 6-7 did not alter basal DA extracellular levels in the NAc (see control groups in figures). For reverse dialysis in the NAc, $5-\mathrm{HT}_{2 \mathrm{C}}$ compounds were first dissolved in their respective vehicle to obtain a $5 \times 10^{-3} \mathrm{M}$ concentration, and then further diluted to the required concentration $\left(10^{-6}\right.$ or
$10^{-7} \mathrm{M}$ ) with aCSF just before use (the $\mathrm{pH}$ of the final solution was not different from that of the aCSF). The perfusion of each compound was maintained during the entire experimental period. Doses, concentrations, and pretreatment administration time of the different $5-\mathrm{HT}_{2 \mathrm{C}} \mathrm{R}$ compounds used were chosen on the basis of dose and concentration range used in previous studies to keep both selectivity and efficiency toward the targeted sites (Filip and Cunningham, 2002; Fletcher et al, 2004; Kennett et al, 1997; Lucas and Spampinato, 2000; Martin et al, 1998; McMahon et al, 2001). All drug doses and concentrations were calculated as the free base. In each experimental group, animals received either drugs or their appropriate vehicle.

\section{Statistical Analysis}

The DA content in each sample was expressed as the percentage of the average baseline level calculated from the three fractions preceding any treatment. Data correspond to the mean \pm SEM values of the percentage obtained in each experimental group. The overall drug effect was calculated as the average of DA content from dialysates collected after their administration. For each brain region, the interaction between cocaine and $5-\mathrm{HT}_{2 \mathrm{C}} \mathrm{R}$ compounds was studied by a two-way ANOVA (pretreatment $\times$ treatment) with time as repeated measures, performed for the eight samples that followed cocaine administration. Thereafter, a one-way ANOVA (using group as the main factor) followed by the Fisher's protected least significance difference test (PLSD) was performed to allow adequate multiple comparisons between groups or, when the two-way ANOVA was not significant $(p>0.05)$, to determine the effect of $5-\mathrm{HT}_{2 \mathrm{C}} \mathrm{R}$ compounds in our experimental conditions. When assessing the influence of intra-NAc perfusion of $1 \mu \mathrm{M}$ SB 242084 on cocaine-induced DA outflow, given the transient nature of the obtained effect, the PLSD test was performed for each time point of the time course.

For each experiment, statistical differences in basal DA values among groups were assessed by a one-way ANOVA (using group as a main factor).

\section{RESULTS}

\section{Histology}

Figure 1 indicates the location of microdialysis probe membranes in the NAc and injection cannula tips in the VTA. In the NAc, all the probe tips were located into the shell. In some cases, a part of the probe membrane overlap to some extent into the medial part of the core. For all experiments, only animals with the probe membrane within the NAc and the cannula tip within the anterior VTA were included for analysis: $\sim 15 \%$ of rats that underwent surgery were excluded.

\section{Basal Extracellular DA Concentrations in Dialysates from the NAc}

All measurements were performed $150 \mathrm{~min}$ after the beginning of perfusion, by which time a steady state was achieved. Absolute basal levels of DA in dialysate collected from the NAc did not differ across experimental groups 


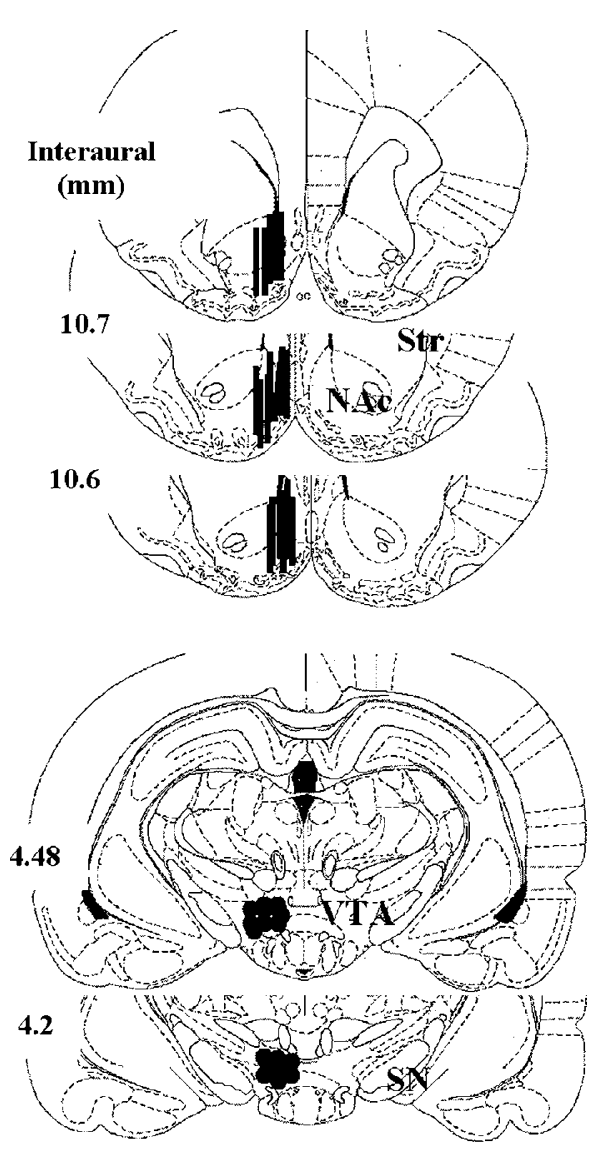

Figure I Histological verification of injection and perfusion sites. Straight lines in the three top coronal sections indicate the location of microdialysis probe membranes $(2 \mathrm{~mm})$ in the NAc. Filled circles in the two bottom coronal sections indicate the location of injection cannula tips in the anterior VTA. Plates are taken from Paxinos and Watson atlas (1986), and the number beside each plate corresponds to millimeters from interaural point. NAc: nucleus accumbens; SN, substantia nigra; Str, striatum; VTA, ventral tegmental area.

throughout the course of the study and were $5.2 \pm 0.3 \mathrm{pg} /$ $30 \mu \mathrm{l}$ (mean \pm SEM, without adjusting for probe recovery; $n=168$ animals).

\section{Effect of Intra-VTA Administration of Ro 60-0175 or SB 242084 on Cocaine-Induced Increase in Accumbal DA Outflow}

Figure 2 illustrates the effects of intra-VTA injection of the 5- $\mathrm{HT}_{2 \mathrm{C}} \mathrm{R}$ agonist Ro 60-0175 at $1 \mu \mathrm{g} / 0.2 \mu \mathrm{l}$ (upper left panel) and $5 \mu \mathrm{g} / 0.2 \mu \mathrm{l}$ (lower left panel) and the $5-\mathrm{HT}_{2 \mathrm{C}} \mathrm{R}$ antagonist SB 242084 at $0.1 \mu \mathrm{g} / 0.2 \mu \mathrm{l}$ (upper right panel) and $0.5 \mu \mathrm{g} / 0.2 \mu \mathrm{l}$ (lower right panel) on the increase in accumbal DA outflow induced by the intraperitoneal (i.p.) administration of cocaine $(10 \mathrm{mg} / \mathrm{kg})$.

As reported previously (Andrews and Lucki, 2001; Navailles et al, 2004), the systemic administration of $10 \mathrm{mg} / \mathrm{kg}$ of cocaine elicited an overall significant increase in accumbal DA efflux, reaching approximately $450 \%$ of baseline ( $p<0.001$, Fisher's PLSD test). Indeed, the effect of cocaine peaked at $650 \%$ of baseline $30 \mathrm{~min}$ after its injection, and thereafter decreased progressively to about $350 \%$ of baseline at the end of the experiment.

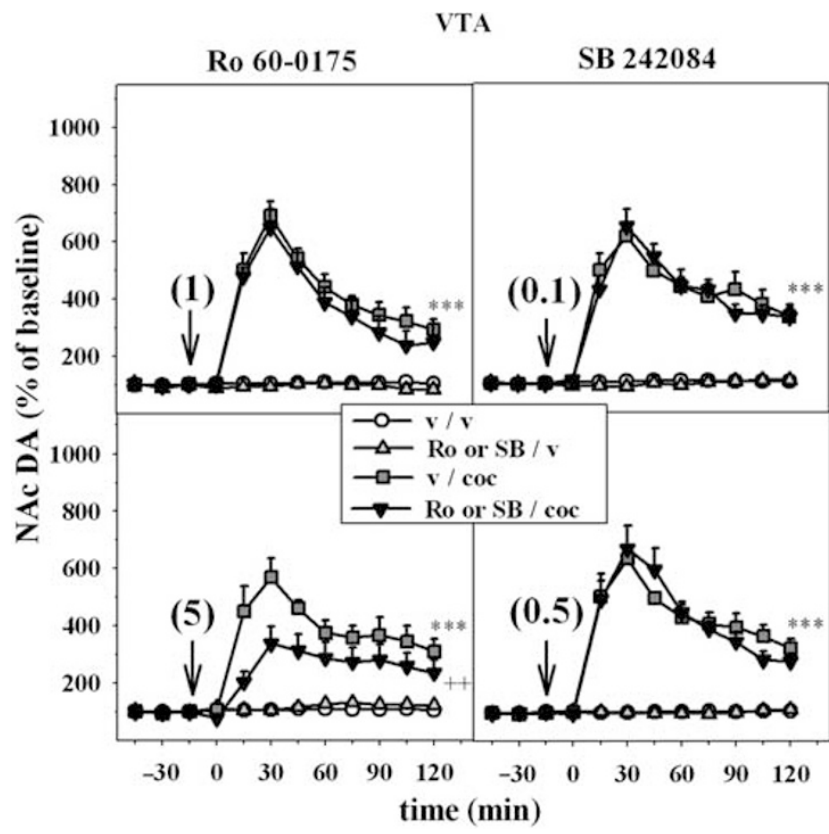

Figure 2 Time course effect of the intra-VTA administration of the 5$\mathrm{HT}_{2} \mathrm{C}$ agonist Ro 60-0I75 and the 5- $\mathrm{HT}_{2} \mathrm{C}$ R antagonist SB 242084 on the increase in accumbal DA outflow induced by cocaine. Ro 60-0I75 (Ro; left panels) and SB 242084 (SB; right panels) were injected into the VTA (vertical arrows) 15 min before cocaine. The doses injected are indicated in parentheses in $\mu \mathrm{g} / 0.2 \mu \mathrm{l}$. Cocaine (coc) was administered intraperitoneally at $10 \mathrm{mg} / \mathrm{kg}$ at time zero. Data are presented as the mean \pm SEM percentages of the baseline calculated from the three samples preceding the first drug administration ( $n=4-8$ animals/group). ${ }^{*} * * * 0.001$ vs the vehicle/vehicle (v/v) group and ${ }^{++} p<0.01$ vs the vehicle/cocaine (v/coc) group (Fisher's PLSD test).

When administered at $1 \mu \mathrm{g} / 0.2 \mu \mathrm{l}$ into the VTA, Ro $60-$ 0175 did not alter the increase in DA extracellular levels induced by cocaine in the NAc (two-way ANOVA, $\mathrm{F}_{1,17}=0.43$, not significant NS; upper left panel). However, when administered at $5 \mu \mathrm{g} / 0.2 \mu \mathrm{l}$ into the VTA, Ro $60-0175$ significantly reduced cocaine-stimulated DA efflux in the NAc (two-way ANOVA, $F_{1,17}=8.5, p<0.01$; lower left panel). Indeed, DA extracellular levels in the NAc after intra-VTA administration of $5 \mu \mathrm{g} / 0.2 \mu \mathrm{l}$ Ro 60-0175 (Ro $60-0175 /$ cocaine group) were significantly lower than those found after vehicle plus cocaine administration $(p<0.01$, Fisher's PLSD test).

The facilitatory effects of cocaine on accumbal DA efflux were not altered by the intra-VTA injection of SB 242084 at either $0.1 \mu \mathrm{g} / 0.2 \mu \mathrm{l}$ (two-way ANOVA, $\mathrm{F}_{1,25}=0.01$, NS; upper right panel) or $0.5 \mu \mathrm{g} / 0.2 \mu \mathrm{l}$ (two-way ANOVA, $\mathrm{F}_{1,20}=6$, NS; lower right panel).

Intra-VTA injections of Ro $60-0175$ or SB 242084 , at either dose, did not alter basal extracellular levels of DA in the NAc (NS, Fisher's PLSD test).

\section{Effect of Intra-NAc Administration of Ro 60-0175 or SB 242084 on Cocaine-Induced Increase in Accumbal DA Outflow}

Figure 3 reports the effects of the intra-NAc infusion of the $5-\mathrm{HT}_{2 \mathrm{C}} \mathrm{R}$ agonist Ro $60-0175$ (left panels) or the $5-\mathrm{HT}_{2 \mathrm{C}} \mathrm{R}$ antagonist SB 242084 (right panels) at $0.1 \mu \mathrm{M}$ (upper 
panels), and $1 \mu \mathrm{M}$ (lower panels) on the increase in accumbal DA extracellular levels induced by cocaine (10 mg/kg i.p.).

The increase in accumbal DA outflow induced by cocaine was significantly and dose-dependently altered by intraNAc infusion of Ro $60-0175$. While $0.1 \mu \mathrm{M}$ of Ro $60-0175$ enhanced (two-way ANOVA, $\mathrm{F}_{1,23}=5.4, p<0.05$; upper left panel), the higher concentration of Ro 60-0175 $(1 \mu \mathrm{M})$ reduced cocaine-evoked DA efflux in the NAc (two-way ANOVA, $\mathrm{F}_{1,22}=6.75, p<0.05$; lower left panel). Indeed, DA extracellular levels in the NAc after 0.1 and $1 \mu \mathrm{M}$ of Ro $60-$ 0175 (Ro 60-0175/cocaine groups) were significantly higher and lower, respectively, than those found in their respective control group (vehicle/cocaine group, $p<0.01, p<0.001$, Fisher's PLSD test).

The increase in DA extracellular levels induced by cocaine was dose-dependently altered by intra-NAc infusion of SB 242084. At a concentration of $0.1 \mu \mathrm{M}, \mathrm{SB} 242084$ significantly reduced cocaine-evoked DA efflux in the NAc (twoway ANOVA, $\mathrm{F}_{1,24}=8.1, p<0.01$; upper right panel). Indeed, cocaine-evoked accumbal DA extracellular levels after intra-NAc infusion of $0.1 \mu \mathrm{M}$ SB 242084 (SB 242084/ cocaine group) were significantly lower than those found in the respective cocaine alone group for the entire experimental period ( $p<0.001$, Fisher's PLSD test).

Intra-NAc infusion of SB 242084 at $1 \mu \mathrm{M}$ elicited a sharp and transient increase of cocaine-induced accumbal DA

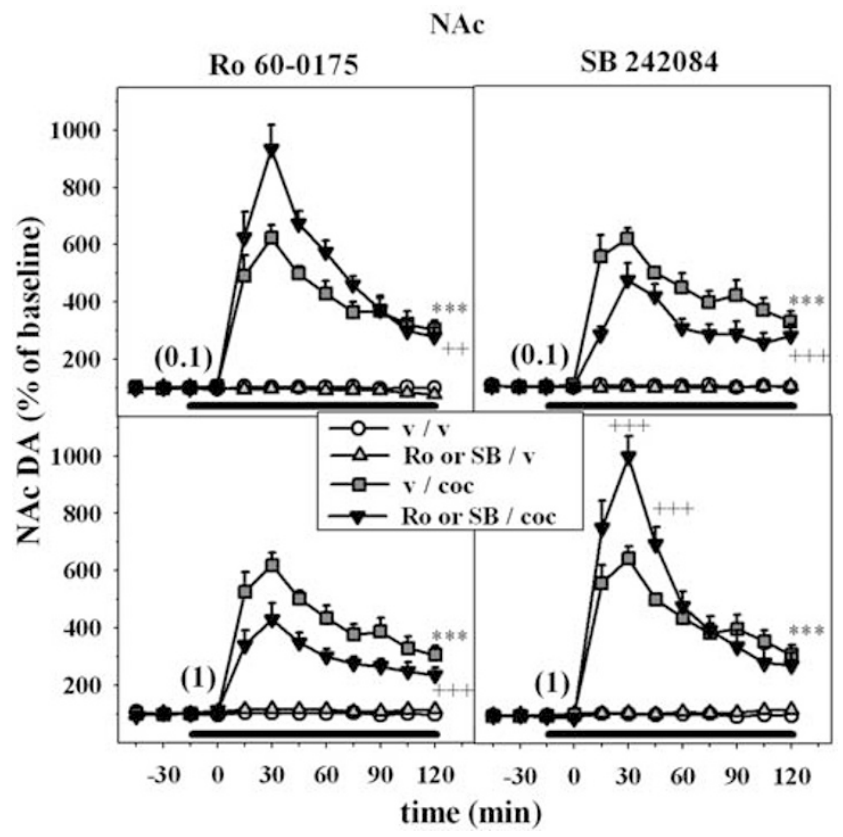

Figure 3 Time-course effect of the intra-NAc administration of the 5$\mathrm{HT}_{2} \mathrm{C}$ agonist Ro 60-0 175 and the $5-\mathrm{HT}_{2} \mathrm{C}$ antagonist SB 242084 on the increase in accumbal DA outflow induced by cocaine. Intra-NAc perfusion of Ro 60-0 175 (Ro; left panels) and SB 242084 (SB; right panels) at $0.1 \mu \mathrm{M}$ (upper panels) and I $\mu \mathrm{M}$ (lower panels) by reverse dialysis started $15 \mathrm{~min}$ before cocaine administration, and were maintained until the end of the experiment (horizontal bars). Cocaine (COC) was administered intraperitoneally at $10 \mathrm{mg} / \mathrm{kg}$ at time zero. Data are presented as the mean \pm SEM percentages of the baseline calculated from the three samples preceding the first drug administration ( $n=4-8$ animals/group). ${ }^{*} * * * 0.00$ I vs the vehicle/vehicle $(v / v)$ group and ${ }^{++} p<0.01,{ }^{+}{ }^{+}+p<0.001$ vs the respective vehicle/cocaine ( $\mathrm{V} / \mathrm{coc}$ ) group (Fisher's PLSD test). efflux, although not significant (two-way ANOVA, $\mathrm{F}_{1,22}=2.2$, NS, lower right panel). However, statistical analysis performed for each time point of the time course revealed that cocaine-evoked accumbal DA extracellular levels after intra-NAc infusion of $1 \mu \mathrm{M}$ SB 242084 (SB 242084 /cocaine group) were significantly higher than those found in the respective cocaine alone group, at 30 and $45 \mathrm{~min}$ after cocaine administration $(p<0.001$, Fisher's PLSD test after a one-way ANOVA, $\left.\mathrm{F}_{3,22}=83, p<0.001\right)$.

Basal DA outflow in the NAc was unaffected by either concentration of Ro 60-0175 or SB 242084 (NS, Fisher's PLSD test).

\section{DISCUSSION}

The present study provides the first direct neurochemical evidence that DA efflux afforded by systemic administration of cocaine is under the control of distinct populations of 5$\mathrm{HT}_{2 \mathrm{C}} \mathrm{R}$ expressed in both the VTA and the NAc, and that this control is balanced between a competing emphasis of actions in the VTA relative to the NAc. Indeed, stimulation of the $5-\mathrm{HT}_{2 \mathrm{C}} \mathrm{R}$ in the VTA resulted in an unidirectional inhibition of cocaine-induced accumbal DA efflux at the doses of Ro 60-0175 studied here, whereas activation of the $5-\mathrm{HT}_{2 \mathrm{C}} \mathrm{R}$ in the NAc effectively stimulated or reduced accumbal DA efflux dependent upon the concentration of Ro 60-0175 utilized. A diametrically opposite response was observed for the $5-\mathrm{HT}_{2 \mathrm{C}} \mathrm{R}$ antagonist SB 242084 such that blockade of the $5-\mathrm{HT}_{2 \mathrm{C}} \mathrm{R}$ within the NAc resulted in a concentration-dependent excitation or inhibition of cocaine-induced DA efflux.

Although a participation of the core compartment of the NAc cannot be excluded within the experimental design used (ie unknown volume of the perfused tissue surrounding the dialysis membrane), it is liable that the present results are related to a preferential involvement of the shell compartment. Indeed, $5-\mathrm{HT}_{2 \mathrm{C}} \mathrm{Rs}$ are expressed at higher levels in the NAc shell compared to the core (Clemett et al, 2000) and they have been specifically targeted by using the most selective and injectable $5-\mathrm{HT}_{2 \mathrm{C}} \mathrm{R}$ compounds presently available (Kennett et al, 1997; Martin et al, 1998; Porter et al, 1999).

In agreement with previous reports (Andrews and Lucki, 2001; Bubar et al, 2003; Navailles et al, 2004; Pontieri et al, 1995), the systemic administration of cocaine elicited a significant increase in DA extracellular levels in the NAc. As suggested by Fletcher et al (2004), we found that cocaineinduced DA outflow was dose-dependently inhibited by the intra-VTA injection of the $5-\mathrm{HT}_{2 \mathrm{C}} \mathrm{R}$ agonist Ro $60-0175$. Despite different affinities of Ro 60-0175 for members of the $5-\mathrm{HT}_{2} \mathrm{R}$ family (Martin et al, 1998; Porter et al, 1999), the observed inhibitory effects of Ro 60-0175 are likely to result from the selective stimulation of the $5-\mathrm{HT}_{2 \mathrm{C}} \mathrm{R}$, over the $5-\mathrm{HT}_{2 \mathrm{~A}} \mathrm{R}$, and $5-\mathrm{HT}_{2 \mathrm{~B}} \mathrm{R}$, in the VTA. This assertion is based upon previous observations that the neurochemical and behavioral effects induced by the intra-VTA administration of Ro 60-0175, at dose regimen similar to that employed here, were prevented by the peripheral administration of the selective $5-\mathrm{HT}_{2 \mathrm{C}} \mathrm{R}$ antagonist SB 242084 (Fletcher et al, 2004; Pozzi et al, 2002). In line with previous results (Pozzi et al, 2002), the ability of the intra-VTA 
injection of Ro 60-0175 to reduce cocaine-induced DA release reveals the existence of a phasic control exerted by $5-\mathrm{HT}_{2 \mathrm{C}} \mathrm{Rs}$ located into the VTA on stimulated DA release. Specifically, the fact that Ro 60-0175 is effective only at the higher doses suggests that increasing the dose of the agonist may lead to a sufficient threshold of activation of a population of the $5-\mathrm{HT}_{2 \mathrm{C}} \mathrm{R}$ in the VTA to induce a significant effect on accumbal DA release.

At variance with VTA $5-\mathrm{HT}_{2 \mathrm{C}} \mathrm{R}$ stimulation, we found that the intra-VTA administration of the selective $5-\mathrm{HT}_{2 \mathrm{C}} \mathrm{R}$ antagonist SB 242084, at doses known to block the inhibitory effect of Ro 60-0175 on accumbal DA release (Navailles et al, 2006b), had no influence on cocaineinduced efflux of DA in the NAc. Also, as reported previously (Navailles et al, 2006b), blockade of the VTA $5-\mathrm{HT}_{2 \mathrm{C}} \mathrm{R}$ had no influence on basal DA release in the NAc, a finding likely reflecting the existence of a low endogenous 5-HT tone at VTA $5-\mathrm{HT}_{2 \mathrm{C}} \mathrm{R}$. In line with these results, $5-\mathrm{HT}_{2 \mathrm{C}} \mathrm{R}$ blockade in the VTA alters neither basal nor cocaine-induced locomotion in rats (Herin et al, unpublished data; McMahon et al, 2001), a response typically related to increased accumbal DA release (Dunnett and Robbins, 1992). Thus, our findings altogether suggest that endogenous 5-HT in the VTA might not play a prominent role in regulating accumbal DA efflux induced by cocaine (McMahon et al, 2001), and demonstrate that the $5-\mathrm{HT}_{2 \mathrm{C}} \mathrm{R}$ in the VTA, through its substantial stimulation by exogenous agonist, is involved in the inhibitory control of cocaine-stimulated DA efflux in the NAc.

Classically, the modulatory actions of the $5-\mathrm{HT}_{2 \mathrm{C}} \mathrm{R}$ locally in the VTA have been associated with its ability to inhibit the neuronal firing of DA-containing neurons through indirect mechanisms (Di Giovanni et al, 2001; Gobert et al, 2000; Navailles et al, 2004). Indeed, GABA neurons in the VTA co-express both the transcript (Eberle-Wang et al, 1997) and the protein for the $5-\mathrm{HT}_{2 \mathrm{C}} \mathrm{R}$ (Bubar and Cunningham, 2006). Electrophysiological studies suggest that stimulation of the $5-\mathrm{HT}_{2 \mathrm{C}} \mathrm{R}$ excites the activity of GABA neurons in the VTA (Di Giovanni et al, 2001; Liu et al, 2000), leading to an inhibition of the firing of VTA DA neurons and a subsequent decrease in accumbal DA release (Di Matteo et al, 2000; Gobert et al, 2000; Navailles et al, 2004). Stimulation of VTA 5- $\mathrm{HT}_{2 \mathrm{C}}$ Rs by Ro 60-0175 may block the behavioral and neurochemical effects of cocaine through this mechanism (Fletcher et al, 2004; Prisco et al, 1994). On the other hand, the failure of the intra-VTA injection of SB 242084 to modulate the effects of cocaine on accumbal DA efflux may result from the massive blockade of the $5-\mathrm{HT}_{2 \mathrm{C}} \mathrm{R}$ in the VTA, which may preclude any possible stimulation of these receptors by cocaine-induced increase in 5-HT levels (Cameron and Williams, 1994). It is noteworthy that DA neurons in the VTA have been recently shown to co-express the protein for the $5-\mathrm{HT}_{2 \mathrm{C}} \mathrm{R}$ (Bubar and Cunningham, 2006; Ji et al, 2006). By this finding, and considering that the $5-\mathrm{HT}_{2 \mathrm{C}} \mathrm{R}$ depolarizes cell membranes by inducing phospholipase C-mediated inositol phosphate accumulation and enhancement of intracellular calcium (Stanford et al, 2005), the stimulation of $5-\mathrm{HT}_{2 \mathrm{C}} \mathrm{Rs}$ located on DA neurons would lead to an excitation of DA neuron activity. However, the finding that the exogenous stimulation of VTA 5- $\mathrm{HT}_{2 \mathrm{C}} \mathrm{Rs}$ inhibits cocaine-evoked DA efflux, suggests that the inhibitory control of accumbal DA outflow could result from a functional balance between both populations of 5- $\mathrm{HT}_{2 \mathrm{C}} \mathrm{Rs}$ located on GABA and DA neurons. Although the functional significance of the $5-\mathrm{HT}_{2 \mathrm{C}} \mathrm{R}$ population expressed on DA neurons remains to be established, these data opens new possibilities in the regulatory mechanisms involved in the control of mesoaccumbens DA neuron activity.

In line with the overall inhibitory control exerted by the central $5-\mathrm{HT}_{2 \mathrm{C}} \mathrm{R}$ on activated mesoaccumbens DA neurons (Navailles et al, 2004), we provide evidence that the 5$\mathrm{HT}_{2 \mathrm{C}} \mathrm{R}$ localized to the NAc also exerts an inhibitory control over cocaine-evoked DA efflux in this terminal region. Indeed, when $1 \mu \mathrm{M}$ of compound was infused into the NAc, Ro 60-0175 and SB 242084 reduced and enhanced respectively cocaine-induced DA efflux in the NAc. These effects are most likely due to the actions of these compounds at $5-\mathrm{HT}_{2 \mathrm{C}} \mathrm{R}$, but not $5-\mathrm{HT}_{2 \mathrm{~A}} \mathrm{R}$ or $5-\mathrm{HT}_{2 \mathrm{~B}} \mathrm{R}$. Indeed, Ro 60-0175 displays 30-fold higher affinity for the $5-\mathrm{HT}_{2 \mathrm{C}} \mathrm{R}$ over the 5- $\mathrm{HT}_{2 \mathrm{~A}} \mathrm{R}$ (Martin et al, 1998) and $\mathrm{SB}$ 242084 shows 160 -fold higher affinity for the $5-\mathrm{HT}_{2 \mathrm{C}} \mathrm{R}$ over the $5-\mathrm{HT}_{2 \mathrm{~A}} \mathrm{R}$ (Kennett et al, 1997). Moreover, at variance with the proposed inhibitory role for $5-\mathrm{HT}_{2} \mathrm{R}$, the $5-\mathrm{HT}_{2 \mathrm{~A}} \mathrm{R}$ exerts facilitatory control over activated mesoaccumbens DA function (Auclair et al, 2004; Broderick et al, 2004; Porras et al, 2002). Finally, while both compounds also bind to the $5-\mathrm{HT}_{2 \mathrm{~B}} \mathrm{R}$, this subtype is not expressed into the NAc (Duxon et al, 1997) and has no influence on the neuronal activity of DA neurons (Di Matteo et al, 2000; Gobert et al, 2000).

The response to $5-\mathrm{HT}_{2 \mathrm{C}} \mathrm{R}$ compounds delivered into the NAc, however, is biphasic such that an excitatory influence over stimulated accumbal DA outflow is uncovered upon infusion of a lower concentration of compound into the NAc. Indeed, Ro 60-0175 and SB 242084, perfused at $0.1 \mu \mathrm{M}$, increased and decreased respectively cocaineinduced DA efflux. In line with this finding, behavioral studies have shown that $5-\mathrm{HT}_{2} \mathrm{Rs}$ expressed into the NAc facilitate cocaine-induced DA-related behaviors (Filip and Cunningham, 2002; McMahon et al, 2001). Thus, our results on the whole provide the first neurochemical evidence that NAc $5-\mathrm{HT}_{2 \mathrm{C}} \mathrm{Rs}$ are able to exert both inhibitory and excitatory controls of accumbal DA outflow induced by cocaine.

The ability of $5-\mathrm{HT}_{2 \mathrm{C}} \mathrm{R}$ compounds to induce dosedependent effects on cocaine-stimulated DA transmission has been already reported in the literature and has been proposed to underline the existence of distinct functional 5$\mathrm{HT}_{2 \mathrm{C}} \mathrm{R}$ populations (Filip and Cunningham, 2002, 2003). Of note, the fact that such biphasic effects are not observed in resting conditions (present results; Navailles et al, 2006b) suggests that the biphasic nature of the response could be specifically related to mechanisms underlying the interactions between $5-\mathrm{HT}_{2 \mathrm{C}} \mathrm{R}$ compounds and cocaine-induced DA release. Interestingly, the NAc receives functionally distinct 5-HT axons that differ in 5-HT transporter (SERT) expression (Brown and Molliver, 2000). This heterogeneous 5-HT innervation could be emphasized by the action of a psychostimulant targeting SERT, like cocaine. In some subregions of the NAc, the lack of SERT, a critical mechanism for inactivation of endogenous 5-HT (Brown and Molliver, 2000), may result in increased 5-HT extracellular levels that would lead to the rapid desensitization of 
5- $\mathrm{HT}_{2 \mathrm{C}} \mathrm{Rs}$ (Berg et al, 2001; Kennett et al, 1994; Marion et al, 2004). Then, it is possible that different populations of $5-\mathrm{HT}_{2 \mathrm{C}} \mathrm{Rs}$ with distinct efficacy for $5-\mathrm{HT}$ and $5-\mathrm{HT}_{2 \mathrm{C}} \mathrm{R}$ compounds may be expressed within the NAc and coupled to different circuits that would lead to either an excitation or an inhibition of NAc DA output. In this context, it is noteworthy that $5-\mathrm{HT}_{2 \mathrm{C}} \mathrm{Rs}$ undergo a region-dependent RNA editing (Burns et al, 1997), a mechanism that generates distinct functional populations of $5-\mathrm{HT}_{2 \mathrm{C}} \mathrm{Rs}$ with different levels of constitutive activity (Niswender et al, 1999; Navailles et al, 2006b) and different desensitization rate (Marion et al, 2004). Specifically, the pattern of $5-\mathrm{HT}_{2 \mathrm{C}} \mathrm{R}$ edited isoforms may determine the response to endogenous 5-HT (Herrick-Davis et al, 1999) and control the signal-tonoise ratio at central 5-HT synapses (Gurevich et al, 2002; Niswender et al, 1999).

In the NAc, $5-\mathrm{HT}_{2 \mathrm{C}} \mathrm{R}$, transcripts are densely expressed in the anterior compartment and appear to localize to medium-sized neurons that express the distribution, localization, and morphology typical of striatal GABA efferent neurons (Eberle-Wang et al, 1997; Morilak et al, 1993). Thus, the stimulation or blockade of $5-\mathrm{HT}_{2 \mathrm{C}} \mathrm{Rs}$ within the NAc might disrupt local GABA circuits and also negative feedback loops to the VTA. Although numerous studies have focused on GABAergic mechanisms involved in the $5-\mathrm{HT}_{2 \mathrm{C}} \mathrm{R}$-dependent modulation of DA function (Di Giovanni et al, 2001), a number of other candidates may contribute, including excitatory factors (ie acetylcholine, glutamate, etc.) that could alter DA release as a consequence of local actions of $5-\mathrm{HT}_{2 \mathrm{C}} \mathrm{Rs}$ in the NAc (Lopez-Gimenez et al, 2001; Obradovic et al, 1996). Among these possibilities, the cellular substrate(s) together with the neuronal circuit(s) involved in the excitatory and inhibitory actions of $5-\mathrm{HT}_{2 \mathrm{C}} \mathrm{Rs}$ on accumbal DA release remain to be determined.

The profile of effects of $5-\mathrm{HT}_{2 \mathrm{C}} \mathrm{R}$ ligands on cocaineinduced accumbal DA efflux after their systemic administration suggests that local actions at the $5-\mathrm{HT}_{2 \mathrm{C}} \mathrm{R}$ summate as composite influence in multiple regions of the mesoaccumbens circuit. Systemic administration of a $5-\mathrm{HT}_{2 \mathrm{C}} \mathrm{R}$ agonist or antagonist is reported to have no effect or potentiate cocaine-induced DA efflux (Navailles et al, 2004). Thus, local actions of $5-\mathrm{HT}_{2 \mathrm{C}} \mathrm{R}$ ligands at the $5-\mathrm{HT}_{2 \mathrm{C}} \mathrm{R}$ into the VTA or the NAc cannot entirely account for the overall inhibitory effect observed after their peripheral administration. Specifically, although the role of NAc $5-\mathrm{HT}_{2 \mathrm{C}} \mathrm{R}$ remains to be unravelled because of the existence of opposite concentration-dependent effects, our findings do not support the previous proposal that the $5-\mathrm{HT}_{2 \mathrm{C}} \mathrm{R}$ resident in the VTA may primarily account for the central inhibitory control this receptor protein exerts over accumbal DA release (Navailles et al, 2004). Conversely, our findings provide support to the idea that central $5-\mathrm{HT}_{2 \mathrm{C}} \mathrm{R}$ inhibitory control of mesoaccumbens DA pathway may be considered as a composite response (Filip and Cunningham, 2002, 2003) involving different $5-\mathrm{HT}_{2 \mathrm{C}} \mathrm{R}$ populations located within multiple brain areas (Clemett et al, 2000; Pompeiano et al, 1994) which are known to provide important efferent control of this DA pathway, such as the prefrontal cortex (Carr et al, 1999; Carr and Sesack, 2000), the hippocampus (Sesack and Pickel, 1990), and the amygdala (McDonald, 1991). This conclusion is further supported by the fact that, in contrast to their systemic effects (De Deurwaerdère et al, 2004; Gobert et al, 2000; Navailles et al, 2006a), intra-VTA or intra-NAc administration of $5-\mathrm{HT}_{2 \mathrm{C}} \mathrm{R}$ ligands has no influence on basal DA release in the NAc (Navailles et al, 2006b; present results).

Finally, the obtained results raise the issue of the role of DA neurons in the effects of $5-\mathrm{HT}_{2 \mathrm{C}} \mathrm{R}$ ligands on DAdependent behavioral responses induced by cocaine. Indeed, considering that the stimulant and reinforcing effects of cocaine depend in large part on elevated DA activity in the NAc (Di Chiara, 2002; Dunnett and Robbins, 1992), 5- $\mathrm{HT}_{2 \mathrm{C}} \mathrm{R}$-dependent control of cocaine-induced behavior is generally thought to be consequent to change of accumbal DA outflow (Filip and Cunningham, 2002; Fletcher et al, 2002, 2004, 2006; Grottick et al, 2000; McMahon et al, 2001; Rocha et al, 2002). Although the present study was performed under different experimental procedures than previous behavioral studies (Filip and Cunningham, 2002; Fletcher et al, 2004; McMahon et al, 2001), it is tempting to consider a possible role of accumbal DA release in the $5-\mathrm{HT}_{2 \mathrm{C}} \mathrm{R}$-dependent control of the behavioral effects of cocaine. In the present study, the use of anesthesia allowed us to inject simultaneously into the VTA specific 5- $\mathrm{HT}_{2 \mathrm{C}} \mathrm{R}$ drugs and monitor their effects on cocaine-induced DA release in the NAc via a dialysis cannula. Nevertheless, previous studies reporting similar modulatory effects of the 5-HT system on striatal and accumbal DA release in either freely moving or anesthetized rats, strongly suggest that anesthesia does not alter the responsiveness of midbrain DA neurons to 5-HT system modulation (Porras et al, 2002). Thus, within the limits of the different experimental design used, our data suggest that the modulation of cocaine-induced accumbal DA efflux triggered by intra-VTA administration of a $5-\mathrm{HT}_{2 \mathrm{C}} \mathrm{R}$ agonist or antagonist (present results) could, at least in part, participate in the parallel changes observed in the behavioral responses (Fletcher et al, 2004; McMahon et al, 2001). Also, the facilitatory influence of NAc shell $5-\mathrm{HT}_{2 \mathrm{C}} \mathrm{R}$ on cocaine-induced behavior (Filip and Cunningham, 2002; McMahon et al, 2001) could be related to their ability to increase accumbal DA efflux. However, in the case of the NAc, the reportedly opposite concentration-dependent effects are also compatible with the possibility that 5$\mathrm{HT}_{2 \mathrm{C}} \mathrm{Rs}$, in line with their expression on non-DA neurons in this brain region (Eberle-Wang et al, 1997), may facilitate cocaine-induced DA behaviors independently of their net action on DA outflow itself, thereby controlling DA transmission by acting downstream from DA neurons. As proposed previously (Navailles et al, 2004), such an indirect mechanism could be related to the ability of $5-\mathrm{HT}_{2} \mathrm{Rs}$ to regulate the phosphorylation of the DA and cyclic $3^{\prime}-5^{\prime}$ adenosine monophosphate regulated phosphoprotein, which is located on dopaminoceptive neurons and involved in the mediation of reinforcing effects of cocaine by processes acting independently of changes of DA outflow (Svenningsson et al, 2002; Zachariou et al, 2002).

In conclusion, this study provides the first biochemical evidence that VTA and NAc 5- $\mathrm{HT}_{2 \mathrm{C}} \mathrm{Rs}$ are differentially recruited in the control of cocaine-evoked DA efflux in the NAc. In the VTA, the substantial stimulation of the 5$\mathrm{HT}_{2 \mathrm{C}} \mathrm{R}$, but not its blockade, inhibited cocaine-induced DA outflow. In the NAc, the concentration-dependent effects of 
5- $\mathrm{HT}_{2 \mathrm{C}} \mathrm{R}$ agonist and antagonist revealed both excitatory and inhibitory controls of cocaine-induced DA outflow. These findings suggest that the net inhibitory effect of central $5-\mathrm{HT}_{2 \mathrm{C}} \mathrm{Rs}$ on cocaine-induced $\mathrm{DA}$ outflow may result from the functional balance between different populations of $5-\mathrm{HT}_{2 \mathrm{C}} \mathrm{Rs}$ within the VTA and the NAc, and within the mesoaccumbens pathway (VTA $v s$ NAc). Finally, these data provide new insights into the prominent role of the $5-\mathrm{HT}_{2 \mathrm{C}} \mathrm{R}$ in the regulatory neurochemistry of mesoaccumbens DA function (Higgins and Fletcher, 2003), and then a better understanding of the therapeutic potential of $5-\mathrm{HT}_{2 \mathrm{C}} \mathrm{R}$ ligands for treating cocaine abuse and dependence (Bubar and Cunningham, 2006; Grottick et al, 2000; Rocha et al, 2002).

\section{ACKNOWLEDGEMENTS}

This work was supported by grants from the National Institute on Drug Abuse DA 00260, DA 020087, and DA13595 (KAC) and Center National de la Recherche Scientifique and Bordeaux 2 University. S Navailles was a fellowship recipient from the Ministère de la Recherche et de l'Enseignement Supérieur during the course of this study. We are grateful to Dr P Weber (F Hoffmann-La Roche, Basel, Switzerland) for the gift of Ro 60-0175.

\section{REFERENCES}

Andrews CM, Lucki I (2001). Effects of cocaine on extracellular dopamine and serotonin levels in the nucleus accumbens. Psychopharmacology 155: 221-229.

Auclair A, Drouin C, Cotecchia S, Glowinski J, Tassin JP (2004). 5-HT2A and alphalb-adrenergic receptors entirely mediate dopamine release, locomotor response and behavioural sensitization to opiates and psychostimulants. Eur J Neurosci 20: 3073-3084.

Azmitia EC, Segal M (1978). An autoradiographic analysis of the differential ascending projections of the dorsal and median raphe nuclei in the rat. J Comp Neurol 179: 641-668.

Berg KA, Stout BD, Maayani S, Clarke WP (2001). Differences in rapid desensitization of 5-hydroxytryptamine2A and 5-hydroxytryptamine $2 \mathrm{C}$ receptor-mediated phospholipase $\mathrm{C}$ activation. J Pharmacol Exp Ther 299: 593-602.

Bowers BJ, Henry MB, Thielen RJ, McBride WJ (2000). Serotonin $5-\mathrm{HT}_{2}$ receptor stimulation of dopamine release in the posterior but not anterior nucleus accumbens of the rat. J Neurochem 75: 1625-1633.

Broderick PA, Olabisi OA, Rahni DN, Zhou Y (2004). Cocaine acts on accumbens monoamines and locomotor behavior via a 5HT2A/2C receptor mechanism as shown by ketanserin: 24-h follow-up studies. Prog Neuropsychopharmacol Biol Psychiatry 28: $547-557$.

Brown P, Molliver ME (2000). Dual serotonin (5-HT) projections to the nucleus accumbens core and shell: relation of the 5-HT transporter to amphetamine-induced neurotoxicity. J Neurosci. 20: 1952-1963.

Bubar MJ, Cunningham KA (2006). Serotonin 5-HT2A and 5-HT2C receptors as potential targets for modulation of psychostimulant use and dependence. Curr Top Med Chem 6: 1971-1985.

Bubar MJ, McMahon LR, De Deurwaerdère P, Spampinato U, Cunningham KA (2003). Selective serotonin reuptake inhibitors enhance cocaine-induced locomotor activity and dopamine release in the nucleus accumbens. Neuropharmacology 44: 342-353.
Burns CM, Chu H, Rueter SM, Hutchinson LK, Canton H, Sanders-Bush E et al (1997). Regulation of serotonin2C receptor G-protein coupling by RNA editing. Nature 387: 303-307.

Callahan PM, Cunningham KA (1995). Modulation of the discriminative stimulus properties of cocaine by 5 -HT1B and 5-HT2C receptors. J Pharmacol Exp Ther 274: 1414-1424.

Cameron DL, Williams JT (1994). Cocaine inhibits GABA release in the VTA through endogenous 5-HT. J Neurosci 14: 6763-6767.

Carr DB, O’Donnell P, Card JP, Sesack SR (1999). Dopamine terminals in the rat prefrontal cortex synapse on pyramidal cells that project to the nucleus accumbens. J Neurosci 19: 11049-11060.

Carr DB, Sesack SR (2000). Projections from the rat prefrontal cortex to the ventral tegmental area: target specificity in the synaptic associations with mesoaccumbens and mesocortical neurons. J Neurosci 20: 3864-3873.

Clemett DA, Punhani T, Duxon MS, Blackburn TP, Fone KC (2000). Immunohistochemical localisation of the $5-\mathrm{HT}_{2 \mathrm{C}}$ receptor protein in the rat CNS. Neuropharmacology 39: 123-132.

Cunningham KA, Callahan PM (1991). Monoamine reuptake inhibitors enhance the discriminative state induced by cocaine in the rat. Psychopharmacology 104: 177-180.

De Deurwaerdère P, Navailles S, Berg KA, Clarke WP, Spampinato $\mathrm{U}$ (2004). Constitutive activity of the serotonin2C receptor inhibits in vivo dopamine release in the rat striatum and nucleus accumbens. J Neurosci 24: 3235-3241.

Di Chiara G (2002). Nucleus accumbens shell and core dopamine: differential role in behavior and addiction. Behav Brain Res 137: $75-114$.

Di Giovanni G, Di Matteo V, La Grutta V, Esposito E (2001). mchlorophenylpiperazine excites non-dopaminergic neurons in the rat substantia nigra and ventral tegmental area by activating serotonin $_{2 \mathrm{C}}$ receptors. Neuroscience 103: 111-116.

Di Matteo V, Cacchio M, Di Giulio C, Esposito E (2002). Role of serotonin $_{2 \mathrm{C}}$ receptors in the control of brain dopaminergic function. Pharmacol Biochem Behav 71: 727-734.

Di Matteo V, Di Giovanni G, Di Mascio M, Esposito E (2000). Biochemical and electrophysiological evidence that RO 60-0175 inhibits mesolimbic dopaminergic function through seroto$\operatorname{nin}(2 \mathrm{C})$ receptors. Brain Res 865: 85-90.

Dremencov E, Newman ME, Kinor N, Blatman-Jan G, Schindler CJ, Overstreet DH et al (2005). Hyperfunctionality of serotonin-2C receptor-mediated inhibition of accumbal dopamine release in an animal model of depression is reversed by antidepressant treatment. Neuropharmacology 48: 34-42.

Dunnett SB, Robbins TW (1992). The functional role of mesotelencephalic dopamine systems. Biol Rev Camb Philos Soc 67: 491-518.

Duxon MS, flanigan TP, Reavley AC, Baxter GS, Blackburn TP, Fone KC (1997). Evidence for expression of the 5-hydroxytryptamine-2B receptor protein in the rat central nervous system. Neuroscience 76: 323-329.

Eberle-Wang K, Mikeladze Z, Uryu K, Chesselet MF (1997). Pattern of expression of the serotonin2C receptor messenger RNA in the basal ganglia of adult rats. J Comp Neurol 384: 233-247.

Filip M, Bubar MJ, Cunningham KA (2004). Contribution of serotonin (5-hydroxytryptamine; 5-HT) 5-HT2 receptor subtypes to the hyperlocomotor effects of cocaine: acute and chronic pharmacological analyses. J Pharmacol Exp Ther 310: 1246-1254.

Filip M, Cunningham KA (2002). Serotonin 5-HT(2C) receptors in nucleus accumbens regulate expression of the hyperlocomotive and discriminative stimulus effects of cocaine. Pharmacol Biochem Behav 71: 745-756.

Filip M, Cunningham KA (2003). Hyperlocomotive and discriminative stimulus effects of cocaine are under the control of serotonin(2C) (5-HT(2C)) receptors in rat prefrontal cortex. J Pharmacol Exp Ther 306: 734-743. 
Fletcher PJ, Chintoh AF, Sinyard J, Higgins GA (2004). Injection of the 5-HT2C receptor agonist Ro60-0175 into the ventral tegmental area reduces cocaine-induced locomotor activity and cocaine self-administration. Neuropsychopharmacology 29: 308-318.

Fletcher PJ, Grottick AJ, Higgins GA (2002). Differential effects of the 5-HT(2A) receptor antagonist M100907 and the 5-HT(2C) receptor antagonist SB242084 on cocaine-induced locomotor activity, cocaine self-administration and cocaine-induced reinstatement of responding. Neuropsychopharmacology 27: 576-586.

Fletcher PJ, Sinyard J, Higgins GA (2006). The effects of the 5HT2C receptor antagonist SB242084 on locomotor activity induced by selective, or mixed, indirect serotonergic and dopaminergic agonists. Psychopharmacology 187: 515-525.

Frankel PS, Cunningham KA (2004). m-Chlorophenylpiperazine (mCPP) modulates the discriminative stimulus effects of cocaine through actions at the 5-HT2C receptor. Behav Neurosci 118: $157-162$.

Gobert A, Rivet JM, Lejeune F, Newman-Tancredi A, AdhumeauAuclair A, Nicolas JP et al (2000). Serotonin(2C) receptors tonically suppress the activity of mesocortical dopaminergic and adrenergic, but not serotonergic, pathways: a combined dialysis and electrophysiological analysis in the rat. Synapse 36: 205-221.

Grottick AJ, Fletcher PL, Higgins GA (2000). Studies to investigate the role of 5-HT(2C) receptors on cocaine- and food-maintained behavior. J Pharmacol Exp Ther 295: 1183-1191.

Gurevich I, Englander MT, Adlersberg M, Siegal NB, Schmauss C (2002). Modulation of serotonin 2C receptor editing by sustained changes in serotonergic neurotransmission. J Neurosci 22: 10529-10532.

Herrick-Davis K, Grinde E, Niswender CM (1999). Serotonin 5HT2C receptor RNA editing alters receptor basal activity: implications for serotonergic signal transduction. J Neurochem 73: 1711-1717.

Higgins GA, Fletcher PL (2003). Serotonin and drug reward: focus on 5- $\mathrm{HT}_{2 \mathrm{C}}$ receptors. Eur J Pharmacol 480: 151-162.

Ikemoto S, Kohl RR, McBride WJ (1997). GABA(A) receptor blockade in the anterior ventral tegmental area increases extracellular levels of dopamine in the nucleus accumbens of rats. J Neurochem 69: 137-143.

Ji S, Zhang Y, Van Cleemput J, Jiang W, Liao M, Li L et al (2006). Disruption of PTEN coupling with 5-HT2C receptors suppresses behavioural responses induced by drug of abuse. Nat Med 12: 324-329.

Kalivas PW, Nemeroff CB (1988). The Mesocorticolimbic Dopamine System. Annals of the New York Academy of Sciences: New York, NY.

Kennett GA, Pittaway K, Blackburn TP (1994). Evidence that 5HT2c receptor antagonists are anxiolytic in the rat Geller-Seifter model of anxiety. Psychopharmacology 114: 90-96.

Kennett GA, Wood MD, Bright F, Trail B, Riley G, Holland V et al (1997). SB 242084, a selective and brain penetrant 5-HT2C receptor antagonist. Neuropharmacology 36: 609-620.

Koob GF (1992). Drugs of abuse: anatomy, pharmacology and function of reward pathways. Trends Pharmacol Sci 13: 177-184.

Liu R, Jolas T, Aghajanian G (2000). Serotonin 5-HT(2) receptors activate local GABA inhibitory inputs to serotonergic neurons of the dorsal raphe nucleus. Brain Res 873: 34-45.

Lopez-Gimenez JF, Mengod G, Palacios JM, Vilaro MT (2001). Regional distribution and cellular localization of 5-HT2C receptor mRNA in monkey brain: comparison with $[3 \mathrm{H}] \mathrm{mesu}-$ lergine binding sites and choline acetyltransferase mRNA. Synapse 42: 12-26.

Lucas G, Spampinato U (2000). Role of striatal serotonin2A and serotonin2C receptor subtypes in the control of in vivo dopamine outflow in the rat striatum. J Neurochem 74: 693-701.
Marion S, Weiner DM, Caron MG (2004). RNA editing induces variation in desensitization and trafficking of 5-hydroxytryptamine 2c receptor isoforms. J Biol Chem 279: 2945-2954.

Martin JR, Bös M, Jenck F, Moreau JL, Mutel V, Sleight AJ et al (1998). 5- $\mathrm{HT}_{2 \mathrm{C}}$ receptor agonists: pharmacological characteristics and therapeutic potential. J Pharmacol Exp Ther 286: 913-924.

McCreary AC, Cunningham KA (1999). Effects of the 5- $\mathrm{HT}_{2 \mathrm{C} / 2 \mathrm{~B}}$ antagonist SB 206553 on hyperactivity induced by cocaine. Neuropsychopharmacology 20: 556-564.

McDonald AJ (1991). Topographical organization of amygdaloid projections to the caudatoputamen, nucleus accumbens, and related striatal-like areas of the rat brain. Neuroscience 44: 15-53.

McMahon LR, Filip M, Cunningham KA (2001). Differential regulation of the mesoaccumbens circuit by serotonin 5hydroxytryptamine 5 -HT2A and 5 -HT2C receptors. J Neurosci 21: 7781-7787.

Morilak DA, Garlow SJ, Ciaranello RD (1993). Immunocytochemical localization and description of neurons expressing serotonin2 receptors in the rat brain. Neuroscience 54: 701-717.

Navailles S, De Deurwaerdère P, Porras G, Spampinato U (2004). In vivo evidence that $5-\mathrm{HT} 2 \mathrm{C}$ receptor antagonist but not agonist modulates cocaine-induced dopamine outflow in the rat nucleus accumbens and striatum. Neuropsychopharmacology 29: $319-326$

Navailles S, De Deurwaerdère P, Spampinato U (2006a). Clozapine and haloperidol differentially alter the constitutive activity of central serotonin2C receptors in vivo. Biol Psychiatry 59: $568-575$.

Navailles S, Moison D, Ryczko D, Spampinato U (2006b). Regiondependent regulation of mesoaccumbens dopamine neurons in vivo by the constitutive activity of central serotonin $2 \mathrm{C}$ receptors. J Neurochem 99: 1311-1319.

Niswender CM, Copeland SC, Herrick-Davis K, Emeson RB, Sanders-Bush E (1999). RNA editing of the human serotonin 5-hydroxytryptamine2C receptor silences constitutive activity. J Biol Chem 274: 9472-9478.

Obradovic T, Imel KM, White SR (1996). Methylenedioxymethamphetamine-induced inhibition of neuronal firing in the nucleus accumbens is mediated by both serotonin and dopamine. Neuroscience 74: 469-481.

Paxinos G, Watson C (1986). The Rat Brain in Stereotaxic Coordinates. Academic Press: New York.

Pazos A, Cortés R, Palacios JM (1985). Quantitative autoradiographic mapping of serotonin receptors in the rat brain. II. Serotonin-2 receptors. Brain Res 346: 231-249.

Pompeiano M, Palacios JM, Mengod G (1994). Distribution of the serotonin 5- $\mathrm{HT}_{2}$ receptor family mRNAs: comparison between $5-\mathrm{HT}_{2 \mathrm{~A}}$ and $5-\mathrm{HT}_{2 \mathrm{C}}$ receptors. Brain Res Mol Brain Res 23: 163-178.

Pontieri FE, Tanda G, Di Chiara G (1995). Intravenous cocaine, morphine, and amphetamine preferentially increase extracellular dopamine in the 'shell' as compared with the 'core' of the rat nucleus accumbens. Proc Natl Acad Sci USA 92: 12304-12308.

Porras G, Di Matteo V, Fracasso C, Lucas G, De Deurwaerdère P, Caccia $\mathrm{S}$ et al (2002). $5-\mathrm{HT}_{2 \mathrm{~A}}$ and $5-\mathrm{HT}_{2 \mathrm{C} / 2 \mathrm{~B}}$ receptor subtypes modulate dopamine release induced in vivo by amphetamine and morphine in both the rat nucleus accumbens and striatum. Neuropsychopharmacology 26: 311-324.

Porter RH, Benwell KR, Lamb H, Malcolm CS, Allen NH, Revell DF et al (1999). Functional characterization of agonists at recombinant human $5-\mathrm{HT}_{2 \mathrm{~A}}, 5-\mathrm{HT}_{2 \mathrm{~B}}$ and $5-\mathrm{HT}_{2 \mathrm{C}}$ receptors in $\mathrm{CHO}-\mathrm{K} 1$ cells. Br J Pharmacol 128: 13-20.

Pozzi L, Acconcia S, Ceglia I, Invernizzi RW, Samanin R (2002). Stimulation of 5-hydroxytryptamine (5-HT(2C)) receptors in the ventrotegmental area inhibits stress-induced but not basal dopamine release in the rat prefrontal cortex. J Neurochem 82: 93-100. 
Prisco S, Pagannone S, Esposito E (1994). Serotonin-dopamine interaction in the rat ventral tegmental area: an electrophysiological study in vivo. J Pharmacol Exp Ther 271: 83-90.

Rocha BA, Goulding EH, O'Dell LE, Mead AN, Coufal NG, Parsons LH et al (2002). Enhanced locomotor, reinforcing, and neurochemical effects of cocaine in serotonin 5-hydroxytryptamine2C receptor mutant mice. J Neurosci 22: 10039-10045.

Sesack SR, Pickel VM (1990). In the rat medial nucleus accumbens, hippocampal and catecholaminergic terminals converge on spiny neurons and are in apposition to each other. Brain Res 527: 266-279.

Stanford IM, Kantaria MA, Chahal HS, Loucif KC, Wilson CL (2005). 5-Hydroxytryptamine induced excitation and inhibition in the subthalamic nucleus: action at 5-HT(2C), 5- $\mathrm{HT}(4)$ and 5 HT(1A) receptors. Neuropharmacology 49: 1228-1234.

Svenningsson P, Tzavara ET, Liu F, Fienberg AA, Nomikos GG, Greengard P (2002). DARPP-32 mediates serotoninergic neurotransmission in the forebrain. Proc Natl Acad Sci USA 99: $3188-3193$.

Yan QS (2000). Activation of 5-HT2A/2C receptors within the nucleus accumbens increases local dopaminergic transmission. Brain Res Bull 51: 75-81.

Zachariou V, Benoit-Marand $\mathrm{M}$, Allen $\mathrm{PB}$, Ingrassia $\mathrm{P}$, Fienberg AA, Gonon F et al (2002). Reduction of cocaine place preference in mice lacking the protein phosphatase 1 inhibitors DARPP-32 or Inhibitor 1. Biol Psychiatry 51: 612-620. 